Article

\title{
Do Agricultural Package Programs Improve the Welfare of Rural People? Evidence from Smallholder Farmers in Ethiopia
}

\author{
Araya Teka ${ }^{1, *(1)}$ and Sung-Kyu Lee ${ }^{2}$ \\ 1 Tigray Institute of Policy Studies (TIPS), 7000 Tigray, Ethiopia \\ 2 Department of International Trade, Andong National University, Andong 36729, Korea; sk162@hanmail.net \\ * Correspondence: arayamebrahtu@gmail.com
}

Received: 26 March 2020; Accepted: 17 May 2020; Published: 25 May 2020

check for updates

\begin{abstract}
The purpose of this paper is to assess the welfare status and analyze the impact of participation in farm package programs on the welfare of smallholder farmers. We used three round panel data of 789 households from the Eastern zone of Tigray, and the fixed effect instrumental variable method was employed in the estimation. The study found that consumption expenditure, income, and asset per capita of the households increased across the survey years. The participation of households in the integrated package programs has a positive and statistically significant impact on the consumption expenditure and calorie per adult equivalent, but not the income and asset per capita of the households. Also, affects the consumption expenditure per adult equivalent of the married households. To enhance the welfare of the beneficiaries, the provision of the package programs should align with the local resource endowment, focus on youth, widowed and divorced households and the government should prioritize and limit the number of packages that households can participate in.
\end{abstract}

Keywords: farm package programs; fixed effect instrumental variable; panel data; smallholder farmers; welfare status

\section{Introduction}

At present, Sub Saharan Africa (SSA) is home to about 224 million undernourished people. It accounts for about 25 percent of the world's undernourished population. In the year 2015, 20.8 percent of the population was undernourished, which has risen tremendously to 22.7 percent in 2016 . Sub Saharan Africa (SSA) countries have worked more to reduce the level of poverty, food insecurity, and nourishment in the region and achieve the United Nations' Sustainable Development Goals [1]. As part of their development agenda, governments have diffused multiple agricultural package programs needed to both increase the productivity of the smallholder farmers and improve the welfare of rural people.

There are two conflicting results about the impact of government-supported farm package programs on the welfare of rural households. Numbers of empirical works support the positive contribution of the various agricultural package programs on consumption, food security, asset building, and related welfare measures [2-6]. Conversely, experiences of some countries and empirical findings showed shreds of evidence for the weak effect of the induced household-based agricultural package programs on the households' poverty, consumption, income, nutrition, and social values [7-10]. Besides, in Ethiopia where this study was conducted, the government has given due attention to the agricultural sectors because agriculture contributed 42.5 percent to GDP, employing about 80 percent of the population and generating 70 percent foreign exchange of the country [11]. However, since Ethiopia 
has an agricultural-based economy, the contribution of the sector to the national economy is considerably affected by recurrent drought, the productivity of the farmers, and the effective implementation of the package programs [12].

Research findings in Ethiopia failed to provide substantial evidence on the impact of the integrated farm package programs on the welfare of the households; rather the researches were focused on a single package, measuring productivity gains, depending on cross-sectional data and unreliable representativeness of the sample. The effect of the agricultural package programs is heterogeneous across regions, economic and social units that initiate area-specific studies by using zone level panel data $[3,13]$.

The major objective of the paper is to assess the welfare status of the smallholder farmers, analyze the impact of household's participation on farm package programs on the welfare and examine to what extent the integration of package programs determines the welfare of rural households using the fixed effect instrumental variable estimation method. Thus, it tries to fill the existing gaps to support policymakers working in the welfare and development of the smallholder farmers.

The paper has six parts. It starts with an introduction in the first part. A brief empirical literature review is placed in the second part followed by the nature of data used, method of data collection, and description of the study area in part 3. The fourth part describes the estimation method used in this article. Detailed interpretation and discussion of the data are presented in part 5 . The last section is the conclusion part which summarizes the major findings.

\section{Literature Review}

Historically, multiple development programs and interventions have been designed and implemented to enhance the productivity and well-being of smallholder farmers. The supports are financial contributions, introducing household-based agricultural technologies, and providing communication, marketing, and organizational systems. The effectiveness of the development and livelihood programs depends on the implementation capacity of the countries, and outcomes also differ considerably.

The profitability of the agricultural sector depends on the investments and activities performed since the preparation of land, the utilization of inputs, proper harvesting, and storing is required [14]. Agricultural productivity has a sizeable and encouraging impact on household consumption growth in Nigeria. However, the result envisaged that, although agrarian productivity has a positive effect on welfare growth for non-poor communities, it hurts poor households. Studies show that more than 50 percent of yields have wasted in the overall production system. Keeping agricultural products in better stores increases the consumption pattern of the families, improves the income, and reduces the level of food insecurity at the household level. Research work done in Ethiopia has provided supporting evidence for the noticeable impact of the improved storage facilities on welfare. The technology helped families to improve their food consumption and ensured dietary diversity, child nutrition, and security [6].

Microfinance institution, as a tool for development intervention, has mixed results. A volume of studies supports the positive contributions of microcredit in income, saving, expenditure, poverty reduction, promote investment and other welfare measures of households in the least developed countries [15-21]. The introduction of group saving programs helped households to transform their livelihood system; changing from agriculture to animal husbandry, would increase human capital development since it raised the educational expenses of families and boosted households' investment in small businesses in Laos [22].

However, other findings ensure that microcredit services alone will not bring economic benefits to households: rather, households using a combination of microcredit and micro insurance services enable them to get the highest improvements in their welfare [23]. Besides, there are research findings that ensure the absence of a significant impact of microcredit related interventions on the welfare of the households in developing nations $[7,8]$. 
The World Food Program introduced the marketing program called Purchase for Progress in 2008, the five-year pilot program of the WFP (2008-2013) in Tanzania but did not support households to raise their income, food consumption score and yields' value [24]. Agricultural package programs which focus on farm input and production subsidy and market-price supports have diversified and systematically different impact on the welfare of households in Ghana, Malawi, Guatemala, Nicaragua, Bangladesh, and Vietnam [25].

Farmers' Field School was an extension program designed to enhance the agricultural development and welfare of the people through the provision and facilitation of experimental, participatory, and advancing learning, and it affects the food security situation of the farmer households but not the level of poverty in Tanzania [9].

A study made by [5] states that an acre land increased in the adoption of improved seed (maize) and reduced the probability of food insecurity level ranging from 0.7 to 1.1 percent in Tanzania. The hybrid and improved sorghum variety had a positive impact on the welfare of Sudanese farmers and helped to shift the consumption level of other cereals, increase the sales coverage, enhance the diet diversification of the households and boost the crop commercialization behavior of the smallholder farmers [26]. Research work in Malawi using panel data and IV estimation techniques on the adoption of improved maize varieties show that decision of households on the use of improved maize seeds has a stronger impact on the welfare of the poor beneficiary households [3].

There is also empirical evidence from Ethiopia and Tanzania on the impact of the adoption of improved chickpea and pigeon pea on welfare. Farmer households who used the improved varieties of the legume crops have a higher level of consumption, lower poverty, higher food security, and greater ability to resist risk [2]. Besides, the participation of households in various farm package programs, in Ethiopia, has a positive impact on the production and productivity of smallholder farmers [13]. Local cooperatives and extension services played for their positive role in ensuring economic success and shifting the poor livelihood of the rural people. In Nigeria, with a different degree of influence, access to extension services and cooperative membership had a substantial and statistically significant effect on the welfare of the rural people [27]. Conversely, a research study from Malawi showed the opposite result. Access to agricultural extension services failed to provide a significant impact on yield and food security in rural areas in Malawi [10].

Most of the time, development interventions focus on the introduction of diversified programs induced by external sources. Little attention has been given to indigenous knowledge and innovations, particularly in the rural area, as a means of development and welfare kit. An empirical study from Ghana revealed that farmer-led innovations considerably enlarges household income, and per capita consumption expenditure, and lowers the level of food insecurity [28]. In Western Kenya, the integrated and innovative pest and soil fertility management strategy which is termed as the 'Push-Pull technology $(\mathrm{PPT})^{\prime}$ has a substantial impact on increasing maize yields and income, raising surplus and reducing the incidence of poverty in the households [4].

Subsidy programs focusing on rural households are also considered as a farm package tool in LDCs. In rural Nigeria, the mobile phone-based voucher subsidy for fertilizer and improved seeds have a mixed effect on the welfare of the households which varies across gender and size of an acre the family owned [27]. There are two contradicting findings concerning the subsidy program in Malawi. The fertilizer subsidy program in Malawi provides viable evidence to enhance the yield per acre, the availability of food grains per adult equivalent, and the number of months with sufficient food in a year for the producer households, but not for the consumers [28]. On the other hand, a fertilizer and seed subsidy program did not support beneficiary households to raise their agricultural productivity and enhance the consumption and food security of families in Malawi [10,29].

The availability of rain is the most influential determinant of agricultural productivity which, in turn, affects consumption. Practicing rain feed agriculture in the least developed countries is hampered for the shortage of rainfall mainly resulting from drought and climate change. To improve productivity and change the livelihood of rural people, nations are investing a lot in irrigation practices. 
Having irrigation facilities, potentials, and access by itself cannot be an end. It has to be accompanied by the efficient utilization of the available resources. A significant number of researches show sufficient empirical evidence for the irrigation's positive impact on the productivity and livelihood of the rural families [30-32]. Further, irrigator households in Mali were raising their consumption level by nearly one-third compared to the irrigation non-users. Besides, it strengthened behavior and increased their participation in social network building and local affairs. The irrigation user households have an accumulated livestock value of 4.5 to 6.4 TLU and had 20 percent higher participation in food sharing with the irrigation non-users [33].

\section{Data and Descriptive Statistics}

\subsection{Farm Package Programs}

Since more than 83 percent of Ethiopians live in rural areas and depend on agriculture as a means of livelihood and employment, the Ethiopian government is implementing rural favored policies and strategies. Depending on the agro-ecological diversity of the country, the movement has introduced various farm package programs to improve the productivity and welfare of the farmers. Farm package programs, here, refer to all the technologies, supplies, and amenities provided by the government in the intention of enhancing the productivity and welfare of the rural community. They are the means to boost consumption, increase household income, and support the building of a household asset [34].

Tigray, as one of the administrative regions in Ethiopia, has implemented the government policies and strategies with minor modifications; in a way to suit the features of the region. Since 2008, the Tigray regional state noticed and highly recognized the role of providing diversified farm package programs in an integrated manner. Therefore, the government has reshaped the implementation of package programs to fulfill the regional aspiration of building a self-reliant region and community. There were eight agricultural package programs provided to the farmer households in Tigray (The package programs are improved seed and fertilizer package, livestock fattening package, dairy package, sheep and goat rear package, beekeeping package, irrigation water harvesting package, poultry package, and tree plantation package). Seventy-three percent of the region's population lives in rural areas, and agriculture is their means of life. Among the rural farming households, 73 percent of them were beneficiaries of agricultural package programs provided by the government. Besides, 76.2 percent of the package members are male-headed households. Farmers are rational to choose the package of their interest; as a result, they participated in one or more of the package programs provided. The improved seed and fertilizer package has the highest number of beneficiaries $(83.7 \%)$, followed by sheep and goat rearing package $(71.8 \%)$ and animal fattening package. Though there are not sufficient package supplies, households are encouraged to participate in the package of their interest [35].

\subsection{Data and Sample Size}

The study used a three three-round balanced panel. It was collected and organized by Adigrat University, the Regional Government of Tigray Bureau of Plan and Finance, Bureau of Agriculture and Rural Development, and Dedebit Credit and Saving Institution (DECSI). The data was collected through a structured questionnaire from seven Woreda (Note that 'Woreda' is the lower administrative organization in Ethiopian government structure which is similar to districts; a group of woreda forms a zone) of the Eastern zone of Tigray-Ethiopia. The Eastern zone is the third most populated zone in the Tigray Region. It has a population size of around one million (2017 est.). Based upon the population size of each Woreda and village, a proportional stratification and simple random probability sampling techniques were used to select the households in the survey. A total of 789 households who were fully covered in the three-round surveys in 2012, 2014 and 2016 were used in the estimation. Enumerators were trained and went to the rural areas to collect the necessary data from the selected households, and respondents were also having full freedom and independence to answer the questions. 
As depicted in Table 1, in the three rounds, 1221 households (51.6\%) were farm package participants and $1146(48.4 \%)$ were non-package beneficiary households. Based upon the total population size of the Woreda, the highest (21.2\%) of the sample size was allocated to SaesieTsaedaEmba followed by Hawzen (17.9\%), AtsbiWenberta (16.7\%), Klteawlaelo (14.7\%), GantaAfeshum (13.1\%), Gulomekeda $(12.7 \%)$, and Erob (3.8\%).

Table 1. Sample size by participation and Woreda.

\begin{tabular}{lcccccc}
\hline \multirow{2}{*}{ District } & \multicolumn{3}{c}{ Package Participation } \\
\cline { 2 - 7 } & \multicolumn{2}{c}{ Non-Member } & \multicolumn{2}{c}{ Member } & \multicolumn{2}{c}{ Total } \\
\cline { 2 - 7 } & No. & \% & No. & \% & No. & \% \\
\hline AtsbiWenberta & 228 & 19.9 & 168 & 13.8 & 396 & 16.7 \\
Erob & 45 & 3.9 & 45 & 3.7 & 90 & 3.8 \\
GantaAfeshum & 129 & 11.3 & 180 & 14.7 & 309 & 13.1 \\
Gulomekeda & 165 & 14.4 & 135 & 11.1 & 300 & 12.7 \\
Hawzen & 180 & 15.7 & 243 & 19.9 & 423 & 17.9 \\
Klteawlaelo & 156 & 13.6 & 192 & 15.7 & 348 & 14.7 \\
SaesieTsaedaEmba & 243 & 21.2 & 258 & 21.1 & 501 & 21.2 \\
Total & 1146 & 48.4 & 1221 & 51.6 & 2367 & 100.0 \\
\hline
\end{tabular}

Note: Authors' calculation based on 2012-2016 IRHAPP survey data.

When we looked at the coverage of each package program (Table A3), 29.7 percent of the package participants were involved in the farm input package program followed by beekeeping package $(13.1 \%)$, poultry package $(12.6 \%)$, dairy package $(10.1 \%)$, sheep and goat rearing package $(9.7 \%)$ and forest development package $(9.2 \%)$. The water harvesting package and livestock fattening package accounted for $8.7 \%$ and $6.9 \%$ of the share, respectively. There was no smooth trend on the number of beneficiaries in each type of package programs across the survey rounds. The share of farm input package programs was 32\% in 2012 which declined to $24.7 \%$ in 2014 and increased again, to $34 \%$ in 2016. Though there were households who introduced all the eight package programs, on average, the sample households participated in 1.4 package programs which range from 1.2-1.7 packages.

\subsection{Descriptive Statistics}

Households participated in the package programs depending on the availability of the package programs, its type, the interest of the households, and the direction of government and quota. The tests, expansions, and discussions, in this part, applied the pooled panel data estimation. As indicated in Table 2, the households' socio-economic characteristics have been tested and similarities and differences were shown, depending on the variables of interest. Household variables like the level of education, family size, and age of the head of the family also remain similar across the participants and non-participant households. The average age of the head of the household is 47.31 years for the package on-members and 47.55 years for the package program beneficiary households. The mean family size is 5.59 and 5.57 persons for the package adopter and non-adopter households, respectively. The level of education of the heads of the households is very low, which might influence the adoption and proper implementation of agricultural package programs, making proper decisions, and evaluating risks of newly introducing technologies.

The well-being of people raises, to a certain extent, when households have better health facilities and reduce the prevalence of disease and death of citizens, full access to food and develop resistance to any form of shocks. The health condition which is expressed by the child mortality, maternal mortality, and the experience of illness for the last 12 months before the survey year, did not differ on the status of households' package participation. Only 1.13 percent of the non-package member households and 1.47 percent of the beneficiaries had lost a child for a health-related problem during the survey years. Almost two women out of one hundred have passed away in the Eastern zone of Tigray for 
health-related problems. Twenty-two and 20 mothers died in the agricultural package non-participants and participants, respectively, across the survey years.

Table 2. Socio-economic features of household features by participation.

\begin{tabular}{|c|c|c|c|}
\hline \multirow[t]{2}{*}{ Welfare and Household Feature } & \multicolumn{3}{|c|}{ Status of Package Participation } \\
\hline & Non-Member & Member & Diff $^{+}$ \\
\hline Death of child under 5 ( $1=$ yes $)$ & $\begin{array}{l}0.0113 \\
(0.106)\end{array}$ & $\begin{array}{l}0.0147 \\
(0.121)\end{array}$ & $\begin{array}{l}-0.0034 \\
(-0.73)\end{array}$ \\
\hline $\begin{array}{l}\text { Number of days family member had a } \\
\text { serious illness in the last } 12 \text { months }\end{array}$ & $\begin{array}{c}2.265 \\
(1.518) \\
\end{array}$ & $\begin{array}{c}2.283 \\
(1.498)\end{array}$ & $\begin{array}{l}-0.018 \\
(-0.29)\end{array}$ \\
\hline Death of mother ( 1 = yes) & $\begin{array}{l}0.0192 \\
(0.137)\end{array}$ & $\begin{array}{l}0.0164 \\
(0.127) \\
\end{array}$ & $\begin{array}{c}0.0028 \\
(0.52)\end{array}$ \\
\hline Months of secured access for food & $\begin{array}{l}8.718 \\
(3.746)\end{array}$ & $\begin{array}{l}9.067 \\
(3.233)\end{array}$ & $\begin{array}{l}-0.349^{* *} \\
(-2.42)\end{array}$ \\
\hline Having savings of various forms ( 1 = year $)$ & $\begin{array}{c}0.541 \\
(0.499)\end{array}$ & $\begin{array}{c}0.609 \\
(0.488)\end{array}$ & $\begin{array}{c}-0.0675^{* * *} \\
(-3.33)\end{array}$ \\
\hline Family size & $\begin{array}{l}5.576 \\
(1.982)\end{array}$ & $\begin{array}{l}5.589 \\
(2.027)\end{array}$ & $\begin{array}{l}-0.013 \\
(-0.16)\end{array}$ \\
\hline Level of education (years) & $\begin{array}{c}2.079 \\
(2.924)\end{array}$ & $\begin{array}{c}2.020 \\
(2.900)\end{array}$ & $\begin{array}{c}0.0598 \\
(0.50)\end{array}$ \\
\hline Gender of the head of household ( 1 = male) & $\begin{array}{c}0.784 \\
(0.412)\end{array}$ & $\begin{array}{c}0.815 \\
(0.389)\end{array}$ & $\begin{array}{c}-0.0313 \text { * } \\
(-1.90)\end{array}$ \\
\hline Age of the head of the family (years) & $\begin{array}{c}47.31 \\
(11.26)\end{array}$ & $\begin{array}{c}47.55 \\
(11.29)\end{array}$ & $\begin{array}{l}-0.247 \\
(-0.53)\end{array}$ \\
\hline Labor person days & $\begin{array}{c}118.4 \\
(89.19) \\
\end{array}$ & $\begin{array}{c}121.3 \\
(88.80) \\
\end{array}$ & $\begin{array}{l}-2.930 \\
(-0.80) \\
\end{array}$ \\
\hline Shock experience $(1=$ yes $)$ & $\begin{array}{c}0.613 \\
(0.487)\end{array}$ & $\begin{array}{c}0.621 \\
(0.485)\end{array}$ & $\begin{array}{c}-0.00736 \\
(-0.37)\end{array}$ \\
\hline Number of observations & 1146 & 1221 & 2367 \\
\hline
\end{tabular}

Furthermore, the reported average number of hours that members of the rural community get a severe illness for less than $60 \mathrm{~h}$. Whereas 2.265 days was the average number of days that the non-package participant household members suffer from the illness; package participant households had an average illness period of 2.283 days. This indicates that the average reported days that the household gets sick, the year before the survey date, is very low, and households are either getting better access to health care services or develop traditional mechanisms to cure illnesses. Besides, getting better nutrition can also support for the low level of serious illness at the household level.

Community-level variables, like the experience of the household for shocks and labor working days of the household used at their farmlands, did not differ among the households. Generally speaking, more than 61 percent of households have experienced shocks, which can significantly influence the welfare of their family members. The shocks were related to loss of their harvest, death of livestock, and an outbreak of epidemic disease, like malaria, and locust swarm, flood, drastic drought, and related difficulties.

Even though the government, various development partners, human rights centers, and stakeholders are working to ensure gender equality in all aspects, still, there are culturally related treatment differences and weak perception towards gender equality. Female-headed households, in the rural areas, partially involved in the economic and social affairs of the community. Females made few social interactions representing their household, receive few supports/cooperation, respect, compassion, 
and auspices. In total, 81.5 percent of the agricultural package beneficiaries and 78.1 percent of the non-beneficiaries are male-headed households. Saving is a big source of future investment. Households have different motives and reasons to make savings. The agricultural package program beneficiary households have more savings (cash and kind) than the non-adopters at a 1 percent level of significance. A total of 60.9 percent and 54.1 percent of the package member households and non-adopters, respectively, have savings of various forms in the intention to smooth consumption and, more critically, livelihood in the future. Ninety percent of the households undertook to save to cover their consumption for the summer season, marriage, commemoration, religious festivity, and social events. The remaining 10 percent of the savings were to cover land-related expenses such as land lease fees, purchase of improved seeds and fertilizer, and labor fees.

Households do not have sufficient availability and access to food every month. While the package beneficiary households had 9.1 months of adequate food, the non-members had 8.7 months. Moreover, the package beneficiary households have more months of enough and plentiful food than the non-beneficiary households, which are statistically significant at 5 percent level of significance.

\subsection{Estimation Method}

This part briefs the estimation methods used to analyze the impact of the integrated agricultural package programs on the welfare of the households. Here, the appropriate welfare indicators or measures used are the consumption, income, asset accumulation, and calorie expressed in the adult equivalent and/or per capita terms at time $t$. Since the participation of households at the package program is believed to be endogenous, the fixed effect instrumental variable panel data estimation model is the appropriate model applied in this paper. The welfare model, which explains the relationship between the dependent variable (welfare outcome) and the explanatory variables, is represented in the following manner (Equation (1)). Let us define $Y_{i t}$ as the welfare outcome indicator and the independent variables $P_{i t}$ which is a dummy variable whether the household participates in the agricultural package program or not ( 1 assumes participation \& 0 not), $H_{i t}$ as household characteristics, $L_{i t}$ as household-level labor availability and $V_{i t}$ as village-level factors, $c_{i}$ as unobserved effect and $\varepsilon_{i}$ disturbance term, then the fixed effect panel estimation is expressed as:

$$
Y_{i t}=\alpha_{0}+\alpha_{1} P_{i t}+\alpha_{2} H_{i t}+\alpha_{3} L_{i t}+\alpha_{4} V_{i t}+c_{i}+\varepsilon_{i t}
$$

When we average Equation (1) by time, then the model is given as:

$$
\bar{Y}_{i}=\alpha_{0}+\alpha_{1} \bar{P}_{i}+\alpha_{2} \bar{H}_{i}+\alpha_{3} \bar{L}_{i}+\alpha_{4} \bar{V}_{i}+c_{i}+\bar{\varepsilon}_{i}
$$

To get rid of the time-invariant unobservable factor, $c_{i}$, differencing Equation (2) from Equation (1) which results in:

$$
\begin{gathered}
Y_{i t}-\bar{Y}_{i}=\alpha_{1}\left(P_{i t}-\bar{P}_{i}\right)+\alpha_{2}\left(H_{i t}-\bar{H}_{i}\right)+\alpha_{3}\left(L_{i t}-\bar{L}_{i}\right)+\alpha_{4}\left(V_{i t}-\bar{V}_{i}\right) \\
+\left(\varepsilon_{i t}-\bar{\varepsilon}_{i}\right)
\end{gathered}
$$

Then, the estimators will be consistent when the condition $\operatorname{cov}\left(X_{i t}, \varepsilon_{i t}\right)=0$ where $X_{i t}$ is the explanatory variable.

In the estimation of the panel data model, special care is required to control the unobserved effect $c_{i}$. The fixed effect transformation is applied, under certain circumstances, to eliminate the fixed unobservable effect. For the lack of sufficient evidence for the strictly exogeneity assumption to hold, we cannot assume that the time-invariant unobserved heterogeneity is not correlated to any other covariates in the model. In such a situation, the fixed effect is efficient and remains consistent under any correlation between time-invariant unobservable heterogeneity and the controls. As a result, the fixed-effect model stated above is the best one since it allows correlation between the individual effects and the covariates which can be differenced or demeaned in the regression process [36]. From the 
fixed effect model Equation (1), the participation variable, $P_{i t}$, is expected to correlate with the error term (endogenous). Thus, the estimation of the welfare model requires the application of the fixed effect instrumental variable estimation model. Since the endogenous variable is binary, Equation (4) is expressed using the probit model. The probit model specifies the probability of $Y_{i t}=1$ conditional on covariate of $X_{i t}$, unobserved individual-specific effects $\alpha$ and unobserved time-specific effects $\gamma$. Thus, it is described by the cumulative standard normal distribution:

$$
P_{i t}=\operatorname{Pr}\left(Y_{i t}=1 \mid X_{i t}, \alpha, \gamma, \beta\right)=\Phi\left(X_{i t}^{\prime} \beta+\alpha_{i}+\gamma_{t}\right)
$$

where $\Phi(\ldots)$ is the cumulative distribution function (the standard normal distribution in the probit model). Alternatively, the probit model is expressed as:

$$
P_{i t}=\operatorname{Pr}\left(Y_{i t}=1 \mid X_{i t}\right)=\int_{-\infty}^{X^{\prime} \beta} 2 \pi^{-\left(\frac{1}{2}\right)} \exp \left(-Z^{2} / 2\right) d z
$$

The marginal effect $(M E)$ for the $\mathrm{k}^{\text {th }}$ explanatory variable is also expressed as:

$$
M E\left(X_{k}\right)=\frac{\partial P}{\partial X_{k}}=\phi\left(\beta_{0}+\beta_{1} X_{1}+\beta_{2} X_{2}+\beta_{3} X_{3} \ldots \ldots \beta_{k} X_{k}\right) \beta_{k}
$$

where $\phi(\cdots)$ denotes the density for the standard normal distribution.

The first stage estimation method of the fixed effect instrumental variable (IV), which is the household's decision to participate in the agricultural package programs is represented as:

$$
P_{i t}=\beta_{0}+\beta_{1} X_{i t}+\beta_{2} I V_{i t}+u_{i t}
$$

When we extended Equation (7),

$$
P_{i t}=\beta_{0}+\beta_{1} H_{i t}+\beta_{2} A_{i t}+\beta_{3} V_{i t}+\beta_{4} H P_{i t}+\beta_{5} T_{i t}+c_{i}+\varepsilon_{i}
$$

where the participation variable $\left(P_{i t}\right)$ is the status of the household in participating agricultural package programs (dummy), $H_{i t}$ is the household features; $A_{i t}$ is the landholding of the household which is expected to increase the households' participation rate. $V_{i t}$ represents village-level variables. The $H P_{i t}$ is an instrumental variable which notifies how happy the household is for he/she lives in a rural area and is measured in a Likert scale of $1-5,5$ being very happy, and $T_{i t}$, also an instrumental variable, shows whether the household has trust in the local administrator and do not hold any grudge with the district administrators or not. The last two variables are the instruments used in the estimation of the fixed effect instrumental variable model. The participation of the households might be influenced by the availability and diversity of the package programs in the villages. The trust and happiness variables captured the human and social capital at the individual and village levels, and affect the decision of the households to participate in the farm package programs. Both variables are expected to affect the participation of the households positively. The number of years a household lived in the rural area and a member of parliament resides in the village were used as instrumental variables for the access to fertilizer subsidy programs in Malawi [3].

Accordingly, our welfare estimation involves two steps: (i) estimate the reduced form regression model (Equation (8)) of household participation decision using the probit and get the generalized residuals, and (ii) include the generalized residuals in the structural welfare equation and estimate the model. The computed fitted value for the decision for participation is structured as:

$$
\hat{P}_{i t}=\hat{\beta}_{1}+\hat{\beta}_{2} \hat{H}_{i t}+\hat{\beta}_{3} \hat{A}_{i t}+\hat{\beta}_{4} \hat{V}_{i t}+\hat{\beta}_{5} \hat{H} P_{i t}+\hat{\beta}_{5} \hat{T}_{i t}+\varepsilon_{i}
$$


Thus, the fixed effect instrumental variable structural model is, then, represented as:

$$
Y_{i t}=\alpha_{0}+\alpha_{1} \hat{P}_{i t}+\alpha_{2} H_{i t}+\alpha_{3} V_{i t}+v_{i t}
$$

The validity of the instruments was checked, and all the preconditions for instrumental variable estimation, such as the instruments must be exogenous and correlate with the endogenous variable: endogeneity test, weak instrument test, and over-identification test, have been fulfilled.

\section{Results}

\subsection{Welfare of Households}

\subsubsection{Consumption Expenditure of Households}

Rural families' consumption came from their production $(71.2 \%)$, market $(23.27 \%)$, and direct support from government or aid agencies $(5.51 \%)$. A productive safety net program was the major source of food for rural households for about 3-6 months while they finished their own produces. The sample households have enough food for 8.9 months and low for 2.76 months. Besides, households have very low food availability and access for about 0.34 months.

Table 3 indicates that the mean expenditure of the households was increased from Birr 1627.15 in 2012 to Birr 2120.5 in 2016 with an average growth rate of 15.56 per year (Birr is the Ethiopian currency, and the official exchange rate was 1\$=17.67 Birr in 2012, Birr 20.1 in 2014, 22.2 Birr in 2016 and 27.56 Birr in 2018. The Ethiopian government used the fixed exchange rate. Prices used in this paper are average zonal prices and adjusted for inflation. Besides, expenditure, here, represents the monthly outlays per household). The total expenditure of the households is heterogeneous among the package beneficiary and non-beneficiary households. In all the survey years, package participant households have higher monthly expenditures, and the difference is statistically significant in the year 2014 , and as pooled at a 5 percent level of significance. Moreover, on average, the total expenditure of the participant and non-participant households grew by 15.4 percent and 14.7 percent, respectively. Food expenditure accounts for 86.1 percent of the average monthly expenditure. The mean monthly expenditure of the agricultural package member households was Birr 2047.3, and the non-participants spent Birr 1898.7. The mean monthly non-food expenditure of the households is estimated at Birr 275.5. The package participant households spent Birr 282.1 for non-food stuff and the non-members expended Birr 269.2. There is a statistically significant (1\%) difference in the magnitude of these expenses favoring the beneficiary households. However, the social category of non-food expenditure is highest for the non-participants, which remains statistically significant in the year 2012 and 2014.

The economically disadvantaged people in Ethiopia had higher social interactions and social relations, which is explained by the monthly or yearly expenses they incurred for social festivity and supports. In Ethiopia-Tigray, poor people have a strong tradition of social cohesion and customs and participate in a multitude of social events such as marriage, death, family events, and other festivities than the middle or high-income people. In the year 2016, although it was insignificant, the package members had higher monthly social expenses than the non-participants. Food expenditure accounted for about 88.04 percent of the total household expenses per month. Expenses for social matters had a share of more than 31 percent of the monthly non-food expenditures of households. This indicates that rural households valued high for social interactions and social events and regarded as the sources of love and affection, and cooperation. Social interactions are greatly considered as a means to solve social problems, share risks, and mitigate difficulties in rural communities. 
Table 3. Household welfare measures for agricultural package participant and non-participant households across the years $2012-2016$.

\begin{tabular}{|c|c|c|c|c|c|c|c|c|c|c|}
\hline \multirow{3}{*}{ Variable/Mean } & \multicolumn{3}{|c|}{2012} & \multicolumn{3}{|c|}{2014} & \multicolumn{3}{|c|}{2016} & \multirow[t]{2}{*}{$2012-2016$} \\
\hline & Non-Member & Member & & Non-Memb & r Member & & Non-Meml & r Member & & \\
\hline & Mean & Mean & Diff. & Mean & Mean & Diff. & Mean & Mean & Diff. & Diff. \\
\hline Total expenditure $^{a}$ & $\begin{array}{l}1583.7 \\
(863.4)\end{array}$ & $\begin{array}{l}1670.6 \\
(942.6)\end{array}$ & -86.89 & $\begin{array}{c}2071.9 \\
(1122.7)\end{array}$ & $\begin{array}{c}2270.8 \\
(1043.3)\end{array}$ & $-198.9^{* *}$ & $\begin{array}{c}2040.4 \\
(1564.2)\end{array}$ & $\begin{array}{c}2200.6 \\
(1592.0)\end{array}$ & -160.2 & $-148.7^{* * *}$ \\
\hline Non-food exp. & $\begin{array}{c}245.0 \\
(175.6)\end{array}$ & $\begin{array}{c}254.3 \\
(166.5)\end{array}$ & -9.267 & $\begin{array}{c}328.0 \\
(162.9)\end{array}$ & $\begin{array}{c}323.2 \\
(177.8)\end{array}$ & 4.808 & $\begin{array}{c}234.7 \\
(179.9)\end{array}$ & $\begin{array}{c}268.9 \\
(183.2)\end{array}$ & $-34.25^{* * *}$ & $-12.90 *$ \\
\hline Food Exp. & $\begin{array}{c}1338.63 \\
(760.2)\end{array}$ & $\begin{array}{c}1654.6 \\
(1235.6)\end{array}$ & -77.6 & $\begin{array}{c}1743.88 \\
(1057.44)\end{array}$ & $\begin{array}{l}1947.61 \\
(959.58)\end{array}$ & $-203.7^{* * *}$ & $\begin{array}{l}1805.74 \\
(1526.1)\end{array}$ & $\begin{array}{c}1931.69 \\
(1541.77)\end{array}$ & -125.95 & $-135.8^{* * *}$ \\
\hline Social exp. & $\begin{array}{c}61.86 \\
(70.45)\end{array}$ & $\begin{array}{c}52.75 \\
(60.24)\end{array}$ & $9.110 *$ & $\begin{array}{c}138.1 \\
(101.0)\end{array}$ & $\begin{array}{c}117.4 \\
(93.04)\end{array}$ & $20.76^{* * *}$ & $\begin{array}{c}68.35 \\
(105.9)\end{array}$ & $\begin{array}{c}83.59 \\
(104.9)\end{array}$ & $-15.23 * *$ & 4.877 \\
\hline Exp. PAE & $\begin{array}{c}409.5 \\
(364.1)\end{array}$ & $\begin{array}{c}419.7 \\
(388.2)\end{array}$ & -10.18 & $\begin{array}{l}597.4 \\
(685.5)\end{array}$ & $\begin{array}{c}636.0 \\
(642.0)\end{array}$ & -38.58 & $\begin{array}{c}432.8 \\
(457.3)\end{array}$ & $\begin{array}{c}462.7 \\
(444.0)\end{array}$ & -29.88 & -26.21 \\
\hline Calorie PAE & $\begin{array}{c}3616.9 \\
(3119.7)\end{array}$ & $\begin{array}{c}4039.1 \\
(3480.9)\end{array}$ & $-422.2 *$ & $\begin{array}{c}4522.5 \\
(3876.7)\end{array}$ & $\begin{array}{c}4235.1 \\
(3850.5)\end{array}$ & 287.4 & $\begin{array}{c}4514.7 \\
(4482.9)\end{array}$ & $\begin{array}{c}4469.4 \\
(4343.3)\end{array}$ & 45.29 & -29.83 \\
\hline Prod. asset & $\begin{array}{c}3652.7 \\
(6270.7)\end{array}$ & $\begin{array}{c}4974.1 \\
(7239.9)\end{array}$ & $-1321.4^{* * *}$ & $\begin{array}{c}7703.2 \\
(17,415.7)\end{array}$ & $\begin{array}{c}7018.1 \\
(10,842.1)\end{array}$ & 685.1 & $\begin{array}{c}4034.2 \\
(7382.2)\end{array}$ & $\begin{array}{c}6444.2 \\
(13,592.3)\end{array}$ & $-2410^{* * *}$ & $-1015.4^{* *}$ \\
\hline Livestock & $\begin{array}{c}23,865.5 \\
(58,584.3)\end{array}$ & $\begin{array}{c}18,623.5 \\
(15,242.1)\end{array}$ & 5242.0 * & $\begin{array}{c}23,958.4 \\
(16,343.6)\end{array}$ & $\begin{array}{c}28,407.8 \\
(30,051.5)\end{array}$ & $-4449.4^{* * *}$ & $\begin{array}{c}27,028.0 \\
(51,242.4)\end{array}$ & $\begin{array}{c}37,097.2 \\
(61,669.3)\end{array}$ & $-10069.2 * *$ & $-3090.3 *$ \\
\hline TLU & $\begin{array}{c}17.99 \\
(38.52)\end{array}$ & $\begin{array}{c}18.82 \\
(38.94)\end{array}$ & -0.83 & $\begin{array}{c}16.61 \\
(13.18)\end{array}$ & $\begin{array}{c}27.41 \\
(169.3)\end{array}$ & -10.80 & $\begin{array}{c}13.61 \\
(21.66)\end{array}$ & $\begin{array}{c}16.50 \\
(16.35)\end{array}$ & $-2.889 * *$ & 23.81 \\
\hline$N$ & 380 & 407 & 787 & 382 & 407 & 789 & 382 & 407 & 789 & 2365 \\
\hline
\end{tabular}

Note: (1) Authors' estimation based on 2012-2016 IRHAPP survey data. (2) significance: ${ }^{* * *} 1 \%,{ }^{* *} 5 \%,{ }^{*} 10 \%$. (3) values in parenthesis are standard deviations. (4) ${ }^{a}$ Birr per month at the

household level, ${ }^{\mathrm{b}}$ the annual value of the asset (Birr) at the household level. 


\subsubsection{Household Asset Holding}

Effective government policies designed to address the extreme poverty and food insecurity improves the asset holding of the households. Asset accumulation is one part of the wealth development at the household level. The asset of the household for estimation is categorized, based on its contribution and benefit, as a productive asset, household asset, and livestock assets.

More than 50 percent of the assets of the sample households accounted for the house furniture and equipment followed by livestock (38.75\%) and productive or farm equipment $(8.24 \%)$. Generally, the value of the asset of households shows an increasing trend across the survey years. In the first round of the survey, the average value of the asset was Birr $57,986.65$, which grew by 14.8 percent a year and reached Birr 76,077.2 in the third round.

For security reasons and as a means of reverence in the community, households need to invest their income on the purchase of assets. Households have a great desire to buy the ordinary assets needed for their farm activities, household equipment, and materials that are worthy of social events. Estimates in Table 3 indicate that households participating in the agricultural package programs owned a higher value of assets compared to their counterparts. In the year 2016, package participant households have Birr 29,895 higher assets than the non-participants, which is statistically significant at 10 percent level of significance. Besides, productive and livestock asset holding also varied with the status of participation, supporting the members 5 and 1 percent level of confidence, respectively.

The livestock holding of the households was increasing from year to year across the three survey rounds both for the participant and non-participant households. To this end, the difference in the value of livestock holdings of the package participants changed from Birr 5242 in 2012 to Birr 4449 in 2014 and Birr 10,069.2 in 2016. The difference was significant at the highest level of confidence. The livestock holding of the household was growing at 22.85 percent where the members boosted their asset holding by around 42 percent and 6.6 percent for the package-participants. When we assessed the livestock holding of the households using the Tropical Livestock Unit (TLU), it exhibits an increasing (19.58\%) and decreasing $(31.59 \%)$ trend during the three survey years. The ostensibly conflicting results of the livestock and TLU indicate that households are specializing their livestock holding; focusing on the quality rather than the quantity of the livestock. In all the survey years, TLU was found to favor the package beneficiary households and the value of the livestock for the last two survey years.

\subsection{Econometric Estimation-Impact Analysis}

We used the fixed-effect instrumental variable model to estimate the relationship between the participation of households in the agricultural package programs and welfare. Four welfare outcome indicators, namely, expenditure, income, asset, and calorie, per adult equivalent/capita, were used in the estimation. The expenditure variable includes both the food and non-food monthly expenditures of the households. The income of the households refers to the annual average monetary value that households got from the crop, livestock products, non-crop income, remittance, off-farm income, and others. The asset holding of households includes both productive and non-productive assets and livestock assets. All the welfare variables are expressed in Birr, and inflation is considered. To control for the endogeneity of the decision of household's to participate in the farm package program, we used the level of happiness of the households as they are living at their villages and households' trust on their local and district administrators as instruments (first stage estimation result is at Table A1). The tests for endogeneity, over-identification, and weak identification are also presented in Table A2.

Table 4 indicates that the participation of households in the agricultural package program has a positive and statistically significant impact on expenditure and calories per adult equivalent. The fixed effect estimation shows that families participating in the farm package programs had 0.39 percent and 0.45 percent higher monthly expenditure per adult equivalent and associated calorie per adult equivalent than the non-beneficiary households, respectively. Even though the difference was not statistically significant, the participation of households in the farm package program is correlated with income positively. The fixed effect estimation results are encouraging and promising since 
the immediate objective of ensuring food security and improving consumption has been achieved. Other studies carried out in different countries also came with similar findings for the positive impact of adopting agricultural technologies of various forms on the welfare of participant households [2,5].

When we controlled the marital status of the head of the household, widowed headed households had 0.246 percent consumption expenditure and 0.23 percent calorie per adult equivalent lower than the married heads of households which are statistically significant at 1 percent and 5 percent level of significance, respectively.

Besides, widowed heads had 0.219 percent lower value of asset holding compared with married households. The widowed heads had lower expenditure per adult equivalent, calorie per adult equivalent, and asset per capita than the married head. Such a result could be due to the supports, cooperation, and favors given to widowed heads that might be insignificant that made them live under a lower economic status. A household's labor composition found that the number of adult male and female laborers in the households had a significant influence on welfare. While the numbers of male laborers positively and significantly affect the total expenditure and calorie per adult equivalent, the number of female laborers only determines the expenditure per adult equivalent. The estimates in Table 4 indicate that one additional male laborer increased expenditure per adult equivalent and calorie per adult equivalent by 4.9 percent and 5.8 percent, respectively. One additional female laborer of the household is correlated with a 6.6 percent increase in expenditure per adult equivalent.

Family size notably changes the welfare of households. In this study, we found that family size negatively influences the welfare of the households in all the four welfare indicators. One additional increase in the family member led household expenditure per adult equivalent and calorie per adult equivalent to fall by 10.4 percent and 5.7 percent, respectively. Besides, each one person increase in the size of the household was associated with a reduction of income and asset holding of the households by 11.4 percent and 10.6 percent, respectively. The statistically significant correlation between the family size and the welfare outcome variables indicates the low contribution of the additional member to the household's welfare. This might be due to the high number of dependent members in the households; the dependency ratio is high $(75.22 \%)$. The package non-member households had statistically significant higher dependency ratio and number of unemployed active age members. Our findings are consistent with the empirical results of other research works [2].

Table 4 further portrays that community-level variables were associated with the welfare of rural people. A one percent increase in the cultivable land of the households was linked with a 0.294 percent increase in the asset per capita holding of the households. The livestock holding of the households expressed as Tropical Livestock Unit (TLU) confidently determined household welfare. A one percent increase in TLU improved the expenditure per adult equivalent by 0.08 percent, which is statistically significant at 5 percent level of confidence. Further, a one percent increase in TLU also was associated with a 0.521 percent increase in household asset holding. 
Table 4. Fixed effect estimation of the relationship between households' participation in agricultural package programs and household welfare.

\begin{tabular}{|c|c|c|c|c|c|c|c|c|}
\hline \multirow[b]{2}{*}{ Covariates } & \multicolumn{2}{|c|}{ Expenditure $^{\mathrm{a}}$} & \multicolumn{2}{|c|}{ Income $^{b}$} & \multicolumn{2}{|c|}{ Asset $^{b}$} & \multicolumn{2}{|c|}{ Calorie $^{\mathrm{a}}$} \\
\hline & Coeff. & s.e. & Coeff. & s.e. & Coeff. & s.e. & Coeff. & s.e. \\
\hline Participation of household in farm package & $0.393 * * *$ & 0.133 & 0.339 & 0.272 & -0.275 & 0.245 & $0.453^{* * *}$ & 0.166 \\
\hline Male-headed household & 0.070 & 0.057 & -0.009 & 0.117 & 0.142 & 0.106 & -0.092 & 0.071 \\
\hline Single-headed households & -0.115 & 0.124 & -0.076 & 0.253 & $-0.387^{*}$ & 0.228 & -0.188 & 0.155 \\
\hline Divorced-headed households & -0.023 & 0.074 & 0.097 & 0.150 & -0.005 & 0.135 & $-0.171^{*}$ & 0.092 \\
\hline Widowed-headed households & $-0.246^{* * *}$ & 0.069 & -0.141 & 0.140 & $-0.219^{*}$ & 0.126 & $-0.230^{* *}$ & 0.086 \\
\hline Male adult labor & $0.049^{* * *}$ & 0.016 & 0.045 & 0.032 & -0.018 & 0.029 & $0.056^{* * *}$ & 0.020 \\
\hline Female adult labor & $0.066^{* * *}$ & 0.017 & 0.007 & 0.034 & 0.018 & 0.031 & 0.018 & 0.021 \\
\hline Age of the head of the household & 0.001 & 0.002 & 0.002 & 0.003 & 0.003 & 0.003 & -0.001 & 0.002 \\
\hline Family size & $-0.104^{* * *}$ & 0.008 & $-0.114^{* * *}$ & 0.017 & $-0.106^{* * *}$ & 0.015 & $-0.057^{* * *}$ & 0.008 \\
\hline $\ln$ (cultivated land owned) & 0.084 & 0.053 & -0.070 & 0.107 & $0.294^{* * *}$ & 0.097 & -0.027 & 0.010 \\
\hline Year 2014 & $0.259^{* * *}$ & 0.040 & $0.781^{* * *}$ & 0.081 & $0.310^{* * *}$ & 0.073 & $0.109^{* *}$ & 0.066 \\
\hline Year 2016 & $0.099^{* *}$ & 0.039 & $0.144^{*}$ & 0.079 & $0.409^{* * *}$ & 0.072 & $0.008^{*}$ & 0.050 \\
\hline $\ln$ (Tropical Livestock Unit) & $0.077^{* * *}$ & 0.019 & 0.029 & 0.039 & $0.521^{* * *}$ & 0.035 & 0.004 & 0.049 \\
\hline Having a saving of various forms & $0.117^{* * *}$ & 0.037 & $0.129 *$ & 0.076 & -0.026 & 0.068 & 0.061 & 0.024 \\
\hline Participation of off-farm activity & $0.081^{* *}$ & 0.039 & $0.177^{* *}$ & 0.080 & $0.162 * *$ & 0.072 & -0.070 & 0.046 \\
\hline Mobile phone subscription & $0.173^{* * *}$ & 0.035 & $0.170^{* *}$ & 0.072 & $0.334^{* * *}$ & 0.065 & $0.104^{* *}$ & 0.049 \\
\hline Participate in 5-6 types of packages & $-0.129^{*}$ & 0.073 & $-0.330^{* *}$ & 0.149 & 0.126 & 0.134 & -0.049 & 0.044 \\
\hline Having access to credit services & $0.224^{* * *}$ & 0.044 & -0.004 & 0.091 & $0.194^{* *}$ & 0.082 & -0.042 & 0.091 \\
\hline Having access to health facilities & $0.083^{* *}$ & 0.039 & 0.047 & 0.080 & $0.130 *$ & 0.072 & $0.081 *$ & 0.055 \\
\hline Getting remittance of various forms & -0.021 & 0.043 & $0.708^{* * *}$ & 0.087 & 0.099 & 0.078 & 0.052 & 0.053 \\
\hline Having access to irrigation services & -0.006 & 0.069 & 0.157 & 0.142 & 0.102 & 0.128 & 0.026 & 0.087 \\
\hline Constant & $5.293^{* * *}$ & 0.127 & $7.467^{* * *}$ & 0.259 & $7.337^{* * *}$ & 0.233 & $8.037^{* * *}$ & 0.157 \\
\hline Prob > chi2 & 0.000 & & 0.000 & & 0.000 & & 0.000 & \\
\hline rho & 0.265 & & 0.275 & & 0.259 & & 0.255 & \\
\hline R-sq overall & 0.205 & & 0.141 & & 0.274 & & 0.022 & \\
\hline $\begin{array}{l}\text { Number of observations } \\
\text { Number of groups }\end{array}$ & $\begin{array}{c}2367 \\
789\end{array}$ & & 789 & & $\begin{array}{c}2367 \\
789\end{array}$ & & $\begin{array}{c}2367 \\
789\end{array}$ & \\
\hline
\end{tabular}

Note: (1) Authors' estimation based on 2012-2016 IRHAPP survey data. (2) Significance: ${ }^{* * *} 1 \%,{ }^{* *} 5 \%,{ }^{*} 10 \%$. Package integration variables are not reported to save space. ${ }^{\text {a }}$ Dependent (welfare) variables are per adult equivalents and explained in logarithmic forms. ${ }^{b}$ Dependent (welfare) variables are per capita (family size) and explained in logarithmic forms. 
Significant numbers of empirical literature suggest that improving households' access to social and economic services made a positive and remarkable contribution to the welfare of households. Table 4 also explains that access to health services, credit and saving institutions, and telecommunication services were determining the welfare outcomes. Households who have access to health services had 8.3 percent higher expenditure per adult equivalent than their counterparts at a 95 percent level of confidence. At a lower level of significance $(10 \%)$, access to health services increased the asset holding of the households by 13 percent. Households in rural areas have very limited financial institutions that are working to curb their financial difficulties. In this regard, the empirical finding shows a mixed impact of access to financial institutions on the welfare of households. We found a positive impact of access to credit and savings institutions on the expenditure and asset building of the households. Farmers who have access to credit and saving institution's alternative services had 22.4 percent higher expenditure per adult equivalent and 19.4 percent more asset holding at 1 percent and 5 percent level of significance, respectively. These findings are consistent with a significant number of empirical works focusing on the link between microfinance services and welfare [15-21]. Information and communication technologies play a fundamental role in bridging the information asymmetry existing in rural areas. This helps households to have updates about price, supply, and demand for products and other social matters. Mobile subscription is found statistically significant to increase all the welfare outcome variables at a higher level of confidence. It is correlated with a 17.3 percent increase in expenditure per adult equivalent, a 17 percent rise in income, a 33.4 percent boost in the asset, and a 10.4 percent change in calorie per adult equivalent of the households.

The participation of the households in off-farm activities, households' saving behavior, and remittance were also found statistically significant variables shaping the welfare of the households. Off-farm participant-households generated 17.7 percent, 16.2 percent, and 8.1 percent higher income, asset, and expenditure per adult equivalent, respectively, at a 5 percent level of significance.

Households who have savings of various forms had better expenditure $(11.7 \%)$ and income per capita $(12.9 \%)$ than their counterparts. Remittance of various forms has strong economic and social benefits to households. In the Eastern zone of Tigray, the people have a good culture of cooperation and supporting families, relatives, and communities indeed of help; especially during a period of drought, risks, and shocks, and festivities like marriage. Our finding also provides evidence for the effectiveness of such cooperation, expressed as remittance, on the welfare of the rural people. The estimation result in Table 4 explains that remittance significantly affects the income per capita of households at a 1 percent level of significance. Households who have remittance supports had 20.8 higher income per capita than their counterparts.

Rural households have allocated their family labor in economic and social activities based on their capability and the return they expected. Farmers do not have full freedom to make decisions on the type and number of agricultural package programs they need to participate in. The local environment might influence farmers' decisions, family and peer pressures, command, and orders from the local government administration and other household variables. Most of the time, top-down decisions on the supply of the package programs have been practiced in the study area. Households' demand for the package programs is rarely considered, and there were situations where households were forced to participate in the farm package programs without their willingness. There are two important ideas raised about the optimal number of package programs that a farmer can participate in. Farmers believe that when they participated in many package programs, their profitability and returns will be high and even compensable from one package to another.

Contrary to this, profitability from the participation in the farm package programs is higher when the farmer participates in selected packages where the farmer can specialize easily. As stated above, the package programs have different features, and a multitude of factors influences their profitability and effectiveness. Thus, efficiency matters for a farmer to be profitable. To address this issue, we used the level of integration expressed by the number of farm package programs that farmers are involved in. 
Table 4 portrays that households participating in five to six package programs have a lower level of income per capita and expenditure per capita at 5 percent and 10 percent level of significance, respectively. Therefore, participating in more package programs reduced the income per capita by 33 percent and expenditure per capita by 12.9 percent. This might happen due to efficiency problems to manage the package programs resulting from lack of skill and capacity, finance, external supports, and proper training.

In rural communities, social interactions and values have a significant role in determining the futurity of the households. Marriage is highly appreciated and greatly respected in the community. Married families are more esteemed than divorced, single, and widowed. They do not encourage divorce due to their religious, and cultural values. In fact, people show special respect for the widowed and express their sympathy and readiness to support. Since the Ethiopian government is expected to offer package programs including various types of package programs, evaluating them in terms of social status is critically worthy.

We treated the single, divorced, and widowed heads as non-couple (unmarried) households for the interest to assess whether the package programs are equally important for the married and unmarried households. The estimated coefficients in Table 5 show that the participation of households in the farm package programs have a statistically significant effect of increasing the consumption expenditure of the married households, but not for the non-couples. Therefore, the participation of the married households in the farm package programs helped to improve their households' food and non-food expenditure per adult equivalent by 39.8 percent. This shows that the package programs do not help all households to capture the same or similar benefits from their participation. Therefore, the provision of the farm package programs in the Eastern zone of Tigray is in favor of the major sampled households; married households. This indicates that the other population groups, like the youth, unmarried, divorced, and widowed, benefit less from the package program.

Besides, Table 5 indicates that the welfare of the married households is influenced, positively and significantly, by access to credit services, mobile phone ownership, male adult labor, female adult labor, male-headed households, and having savings of various forms. Furthermore, one person increase in the family size of the married households is associated with a 10.1 percent reduction in the expenditure per adult equivalent.

Table 5. Comparison of the fixed effect estimation of consumption expenditure adult equivalent by marriage status.

\begin{tabular}{lcccc}
\hline \multirow{2}{*}{ Covariates } & \multicolumn{2}{c}{ Log of Expenditure per Adult Equivalent } \\
\cline { 2 - 5 } & Unmarried & s.e & Married & s.e \\
\hline Participation of household in farm package & -1.500 & 1.561 & $0.398^{* *}$ & 0.160 \\
\hline Male-headed household & -0.534 & 0.340 & $0.176^{* *}$ & 0.081 \\
\hline Male adult labor & 0.002 & 0.102 & $0.057^{* * *}$ & 0.018 \\
\hline Female adult labor & -0.010 & 0.147 & $0.080^{* * *}$ & 0.019 \\
\hline Age of the head of the household & 0.002 & 0.010 & 0.001 & 0.002 \\
\hline Having access to health facilities & 0.340 & 0.290 & 0.031 & 0.047 \\
\hline Family size & -0.095 & 0.058 & $-0.101^{* * *}$ & 0.010 \\
\hline ln(cultivated land owned) & -0.310 & 0.500 & 0.090 & 0.062 \\
\hline Year 2014 & 0.121 & 0.363 & $0.204^{* * *}$ & 0.047 \\
\hline Year 2016 & $0.816^{*}$ & 0.470 & 0.025 & 0.046 \\
\hline ln(Tropical Livestock Unit) & 0.114 & 0.161 & $0.058^{* *}$ & 0.024 \\
\hline Having a saving of various forms & -0.012 & 0.310 & $0.102^{* *}$ & 0.043 \\
\hline Participation of off-farm activity & -0.192 & 0.358 & 0.051 & 0.047 \\
\hline
\end{tabular}


Table 5. Cont.

\begin{tabular}{lcccc}
\hline \multirow{2}{*}{ Covariates } & \multicolumn{3}{c}{ Log of Expenditure per Adult Equivalent } \\
\cline { 2 - 5 } & Unmarried & s.e & Married & s.e \\
\hline Mobile phone subscription & 0.371 & 0.298 & $0.156^{* * *}$ & 0.041 \\
\hline Participate in 5-6 types of packages & 0.327 & 0.706 & -0.092 & 0.086 \\
\hline Having access to credit services & 0.394 & 0.328 & $0.255^{* * *}$ & 0.054 \\
\hline Getting remittance of various forms & -0.181 & 0.304 & -0.022 & 0.049 \\
\hline Having access to irrigation services & -0.453 & 0.483 & -0.051 & 0.084 \\
\hline Constant & $6.137^{* * *}$ & 0.886 & $5.246^{* * *}$ & 0.148 \\
\hline Number of observations & 498 & & 1869 & \\
Number of groups & 396 & & 781 & \\
\hline
\end{tabular}

Note: (1) Authors' estimation based on 2012-2016 IRHAPP survey data. (2) Significance: ${ }^{* * *} 1 \%,{ }^{* *} 5 \%,{ }^{*} 10 \%$.

\section{Conclusions}

Implementing the farm package programs is believed to improve the welfare of the rural people through their effects on consumption, income, asset, and transforming the productivity of the smallholder farmers. To study the impact of the farm package programs on welfare, we used balanced three-round panel data of 789 households in the Eastern zone of Tigray and analyzed this data using a fixed-effect instrumental variable panel data model. Expenditure and asset holding of both the participant and non-package beneficiary grew in the period 2012-2016. However, the groups differ significantly in terms of supporting the beneficiaries. Further, there is a heterogeneity effect of the welfare variables among the farm package members and non-members across Woreda.

There is a heterogeneous and righteous impact of participating in agricultural package programs on increasing the expenditure per adult equivalent and the calorie intake of the adopters but not on improving income and household asset creation. Participation in the package programs is associated with a 37.8 percent increase in expenditure per adult equivalent and a 45.3 percent change in calorie intake per adult equivalent. The significant impact of the farm program on the consumption expenditure and calorie indicates the positive role of the programs in boosting welfare, reducing the level of poverty and progresses the food security in the Eastern zone of Tigray. Furthermore, the welfare of the household, additionally, is determined by marital status, adult family labor, family size, size of cultivated area, livestock holding, access to health and credit services, mobile subscription, level of package integration, and remittance. Participation heterogeneously affected households' welfare across different marital statuses. It supported the married households, and its impact on the consumption expenditure and calorie per adult equivalent is statistically significant.

To increase the impact of the agricultural package programs on households' welfare, the following are the alternative tools: (i) designing alternative implementation mechanism, (ii) providing packages focusing on youth divorced and widowed heads of the families, (iii) introducing area targeting package programs, (iv) educating and motivating households to participate in package programs where the return is high, and (v) improving the access for highly demanded package programs.

Author Contributions: A.T. conceptualized the idea and developed the methodology, carried out the formal analysis and writing up. S.-K.L. validated the idea and methodology, refine objectives, editing and reviewing. All authors have read and agreed to the published version of the manuscript.

Funding: Part of this reach was funded by Adirgat University.

Acknowledgments: The authors would like to express their gratitude to Adigrat University, the Regional Government of Tigray Bureau of Plan and Finance, Bureau of Agriculture and Rural Development and Dedebit Credit \& Saving Institution for their financial support and participation in the development of the dataset.

Conflicts of Interest: The authors declare that there is no conflict of interest associated to this article. The funders had no role in the overall process of the research. 


\section{Appendix A}

Table A1. The first stage probit model of decisions to participate in a package program.

\begin{tabular}{lcc}
\hline \multicolumn{1}{c}{ Covariates } & Dep. Variable: Package Participation Decision & s.e \\
\hline Happiness index being lived in the village ${ }^{\text {a }}$ & $0.096^{*}$ & 0.051 \\
Having trust in the gov. administration ${ }^{\mathrm{a}}$ & $0.787^{* * *}$ & 0.067 \\
Gender of the head & $0.169^{*}$ & 0.099 \\
Male adult labor & -0.016 & 0.027 \\
Female adult labor & 0.030 & 0.029 \\
Age of the head & -0.000 & 0.003 \\
Access to health service & -0.105 & 0.067 \\
Level of education of the head & -0.001 & 0.011 \\
Family size & -0.003 & 0.014 \\
Log of cultivated area & 0.142 & 0.087 \\
Year 2014 & $-0.226^{* * *}$ & 0.078 \\
Year 2016 & 0.040 & 0.077 \\
Log of tropical Livestock Unit & 0.033 & 0.032 \\
Households have savings & -0.059 & 0.064 \\
Practicing in off-farm activity & -0.019 & 0.068 \\
Households have a mobile phone & -0.074 & 0.061 \\
Participating in one package & $0.250^{* *}$ & 0.098 \\
Participating in 2-3 packages & $0.483^{* * *}$ & 0.089 \\
Participating in 4-5 packages & $0.657^{* * *}$ & 0.129 \\
Participating in 6-8 packages & $0.481^{* *}$ & 0.205 \\
Have access to credit services & $-0.260^{* * *}$ & 0.078 \\
Have remittance supports & $0.144^{*}$ & 0.074 \\
Have access to irrigation & 0.145 & 0.120 \\
Constant & $-0.997^{* * *}$ & 0.295 \\
chi2 & 285.75 & \\
Prob > chi2 & 0.0000 & -1467.276 \\
Nog-likelihood & 2367 & \\
\hline Number of observations & & \\
\hline
\end{tabular}

Note: (1) Authors' estimation based on 2012-2016 IRHAPP survey data. (2) Significance: ${ }^{* * *} 1 \%, * * 5 \%, * 10 \%$. (3) a these variables are instruments. 
Table A2. Tests for endogeneity, over-identification and weak identification.

\begin{tabular}{lcccc}
\hline \multicolumn{1}{c}{ Test } & Expenditure & Income & Asset & Calorie \\
\hline Under-identification test (Anderson canon. corr. LM statistic): & & & & \\
Chi-sq(2) P-val & & & & \\
Weak identification test (Cragg-Donald Wald F statistic): & & & & \\
58.627 & 110.911 & 110.911 & 110.911 & 0.911 \\
Stock-Yogo weak ID test critical values: & 0.0000 & 0.0000 & 0.0000 & \\
10\% maximal IV size 19.93 & & & & \\
15\% maximal IV size 11.59 & & & & 0.013 \\
20\% maximal IV size $\quad 8.75$ & & & & \\
25\% maximal IV size $\quad 7.25$ & 1.360 & 3.862 & 0.047 & \\
& 0.2435 & 0.5107 & 0.8282 & 0.9076 \\
\hline Sargan statistic (over-identification test of all instruments): & 8.160 & 0.433 & 1.624 & 9.001 \\
Chi-sq(1) P-val & 0.0043 & 0.0494 & 0.0202 & 0.0027 \\
\hline Endogeneity test of endogenous regressors: & & & \\
Chi-sq(1)P-val &
\end{tabular}

Note: (1) Authors' estimation based on 2012-2016 IRHAPP survey data.

Table A3. Number of beneficiaries by type of package.

\begin{tabular}{|c|c|c|c|c|c|c|c|}
\hline \multirow{2}{*}{ Type of Package } & \multicolumn{6}{|c|}{ Year } & \multirow{2}{*}{ Average Share } \\
\hline & 2012 & $\%$ & 2014 & $\%$ & 2016 & $\%$ & \\
\hline Farm Input & 169 & 32.0 & 166 & 24.7 & 165 & 34.0 & 29.7 \\
\hline Livestock Fattening & 46 & 8.7 & 49 & 7.3 & 51 & 10.5 & 8.7 \\
\hline Sheep and goat rearing & 50 & 9.5 & 68 & 10.1 & 46 & 9.5 & 9.7 \\
\hline Water harvesting & 32 & 6.1 & 47 & 7.0 & 37 & 7.6 & 6.9 \\
\hline Dairy & 58 & 11.0 & 73 & 10.9 & 39 & 8.0 & 10.1 \\
\hline Forest & 37 & 7.0 & 92 & 13.7 & 26 & 5.3 & 9.2 \\
\hline Poultry & 67 & 12.7 & 86 & 12.8 & 60 & 12.3 & 12.6 \\
\hline Beekeeping & 69 & 13.1 & 90 & 13.4 & 62 & 12.8 & 13.1 \\
\hline Total & 528 & 100.0 & 671 & 100.0 & 486 & 100.0 & 100.0 \\
\hline
\end{tabular}

Note: (1) Authors' estimation based on 2012-2016 IRHAPP survey data. 


\section{References}

1. FAO [Food and Agriculture Organization]. Regional Overview of Food Security and Nutrition in Africa in 2017: The Food Security and Nutrition-Conflict Nexus: Building Resilience for Food Security, Nutrition, and Peace; FAO: Accra, Ghana, 2017.

2. Asfaw, S.; Shiferaw, B.; Simtowe, F.; Lipper, L. Impact of modern agricultural technologies on smallholder welfare: Evidence from Tanzania and Ethiopia. Food Policy 2012, 37, 283-295. [CrossRef]

3. Bezu, S.; Kassie, G.T.; Shiferaw, B.; Ricker-Gilbert, J. Impact of Improved Maize Adoption on Welfare of Farm Households in Malawi: A Panel Data Analysis. World Dev. 2014, 59, 120-131. [CrossRef]

4. Kassie, M.; Stage, J.; Diiro, G.; Muriithi, B.; Muricho, G.; Ledermann, S.T.; Khan, Z. The push-pull farming system in Kenya: Implications for economic and social welfare. Land Use Policy 2018, 77, 186-198. [CrossRef]

5. Wossen, T.; Abdoulaye, T.; Alene, A.; Haile, M.G.; Feleke, S.; Olanrewaju, A.; Manyong, V. Impacts of extension access and cooperative membership on technology adoption and household welfare. J. Rural Stud. 2017, 54, 223-233. [CrossRef] [PubMed]

6. Tesfaye, W.; Tirivayi, N. The impacts of postharvest storage innovations on food security and welfare in Ethiopia. Food Policy 2018, 75, 52-67. [CrossRef]

7. Annim, S.K.; Dasmani, S.; Armah, M. Does Access and Use of Financial Service Smoothen Household Food Consumption? MPRA Paper No. 29278; University Library of Munich: Munich, Germany, 2011.

8. Coleman, B.E. Microfinance in Northeast Thailand: Who benefits and how much? World Dev. 2006, 34, 1612-1638. [CrossRef]

9. Larsen, A.F.; Lilleør, H.B. Beyond the Field: The Impact of Farmer Field Schools on Food Security and Poverty Alleviation. World Dev. 2014, 64, 843-859. [CrossRef]

10. Ragasa, C.; Mazunda, J. The impact of agricultural extension services in the context of a heavily subsidized input system: The case of Malawi. World Dev. 2018, 105, 25-47. [CrossRef]

11. Central Statistical Authority. National Labor Force Survey Report; Central Statistical Authority: Addis Ababa, Ethiopia, 2013.

12. World Bank. 5th Ethiopian Economic Update. Why so Idle? Wages and Employment in a Crowded Labor Market; World Bank: Washington, DC, USA, 2016.

13. Teka, A.M.; Lee, S.-K. The impact of agricultural package programs on-farm productivity in Tigray-Ethiopia: Panel data estimation. Cogent Econ. Financ. 2019, 7. [CrossRef]

14. Amare, M.; Cisséb, J.D.; Jensenb, N.D.; Shiferawa, B. The Impact of Agricultural Productivity on Welfare Growth of Farm Households in Nigeria: A Panel Data Analysis; FAO: Rome, Italy, 2016.

15. Choudhury, A.H.; Das, A.; Rahman, A. The Effectiveness of Micro-credit Programmes Focusing on Household Income, Expenditure, and Savings: Evidence From Bangladesh. J. Compet. 2017, 9, 34-44. [CrossRef]

16. Imai, K.S.; Arun, T.; Annim, S.K. Microfinance and Household Poverty Reduction: New Evidence from India. World Dev. 2010, 38, 1760-1774. [CrossRef]

17. Khandker, S.R. Microfinance and Poverty: Evidence Using Panel Data from Bangladesh. World Bank Econ. Rev. 2005, 19, 263-286. [CrossRef]

18. Lønborg, J.H.; Rasmussen, O.D. Can Microfinance Reach the Poorest: Evidence from a Community-Managed Microfinance Intervention. World Dev. 2014, 64, 460-472. [CrossRef]

19. Luan, D.X.; Bauer, S. Does credit access affect household income homogeneously across different groups of credit recipients? Evidence from rural Vietnam. J. Rural Stud. 2016, 47, 186-203. [CrossRef]

20. Mahjabeen, R. Microfinancing in Bangladesh: Impact on households, consumption, and welfare. J. Policy Model. 2008, 30, 1083-1092. [CrossRef]

21. Munyegera, G.K.; Matsumoto, T. Mobile Money, Remittances, and Household Welfare: Panel Evidence from Rural Uganda. World Dev. 2016, 79, 127-137. [CrossRef]

22. Sengsourivong, K.; Fumiharu, M. Impacts of Savings Groups Programs on Household Welfare in Laos: Case Study of the Vientiane Vicinity during the Mid-2000s. Southeast Asian Stud. 2015, 3, 85-111.

23. Akotey, J.O.; Adjasi, C.K.D. Does Microcredit Increase Household Welfare in the Absence of Microinsurance? World Dev. 2016, 77, 380-394. [CrossRef]

24. Lentz, E.; Upton, J. Benefits to smallholders? Evaluating the World Food Programme's Purchase for Progress pilot. Glob. Food Secur. 2016, 11, 54-63. [CrossRef] 
25. Erik, J.; Mateusz, F.; Jonathan, B.; JEdward, T. Modeling the Welfare Impacts of Agricultural Policies in Developing Countries. In Proceedings of the International Association of Agricultural Economists (IAAE) Triennial Conference, Foz do Iguaçu, Brazil, 18-24 August 2012.

26. Smale, M.; Assima, A.; Kergna, A.; Theriault, V.; Weltzien, E. Farm family effects of adopting improved and hybrid sorghum seed in the Sudan Savanna of West Africa. Food Policy 2018, 74, 162-171. [CrossRef] [PubMed]

27. Wossen, T.; Abdoulaye, T.; Alene, A.; Feleke, S.; Ricker-Gilbert, J.; Manyong, V.; Awotide, B.A. Productivity and Welfare Effects of Nigeria's e-Voucher-Based Input Subsidy Program. World Dev. 2017, 97, 251-265. [CrossRef] [PubMed]

28. Tambo, J.A.; Wünscher, T. Farmer-led innovations and rural household welfare: Evidence from Ghana. J. Rural Stud. 2017, 55, 263-274. [CrossRef]

29. Sibande, L.; Bailey, A.; Davidova, S. The impact of farm input subsidies on household welfare in Malawi. In Proceedings of the International Conference on Agricultural Economists, Agriculture in an Integrated World, Milan, Italy, 25 May 2015.

30. Dhehibi, B.; Ahmed, A.; El-Shahat, I.A.; Hassan, A.A. Impacts of Irrigation on Agricultural Productivity in Egypt. Ann. Arid Zone 2016, 55, 67-78.

31. Jin, S.; Yu, W.; Jansen, H.G.P.; Muraoka, R. An Impact of Irrigation on Agricultural Productivity: Evidence from India. In Proceedings of the International Association of Agricultural Economists (IAAE) Triennial Conference, Foz do Iguaçu, Brazil, 18-24 August 2012.

32. Todkari, G.U. Impact of Irrigation on Agriculture Productivity in Solapur District of Maharashtra State. Int. J. Agric. Sci. 2012, 4, 165-167.

33. Dillon, A. The Effect of Irrigation on Poverty Reduction, Asset Accumulation, and Informal Insurance: Evidence from Northern Mali. World Dev. 2011, 39, 2165-2175. [CrossRef]

34. Ministry of Finance and Economic Development Ethiopia (MoFED). Building on Progress A Plan for Accelerated and Sustained Development to End Poverty (PASDEP). (2005/06-2009/10); Volume I-main text; MoFED: Ababa, Ethiopia, 2006.

35. Bureau of Finance and Economic Development (BoFED). Impact of Integrated Household Agricultural Package Programs on Poverty and Food Security in Tigrai Regional National State; BoFED: Mekelle, Ethiopia, 2013.

36. Wooldridge, J.M. Introductory Econometrics: A Modern Approach, 5th ed.; Cengage Learning: Boston, MA, USA, 2013. 